\title{
Financial Performance Analysis of Selected Private Commercial Banks in Ethiopia: Using a CAMEL Rating Approach
}

\author{
Tamrat Kasa \\ Lecturer, Department of Management, College of Business and Economics, Dire Dawa University \\ PO Box: 1362
}

\begin{abstract}
This study analyzes the performance and financial credibility of Private Commercial banks in Ethiopia for the period of 2013-2019. This period is taken to consider the political instability and social unrest in the country. As one of the most popular methods for measuring banking performance, CAMELS method is used to analyze the performance of the banks. The good performance of the financial institutions must for the sustainable growth of economy Therefore, this research paper makes analysis of performance of selected private banks in Ethiopia under political instability. The finding indicates that performance of banks in 2016 were decreased than any other year in terms of profit, profit per employee, loan and net income. Cost to income ratio increased. The result implies employee productivity of banks were decreased in 2016, where there were high social and political unrest in the country. Therefore, banks should not concentrate in a single region and has diversify their operations across regions.
\end{abstract}

Keywords: financial performance, CAMEL approach, Political instability, private banks

DOI: $10.7176 /$ RJFA/12-19-04

Publication date:October $31^{\text {st }} 2021$

\section{Introduction}

The financial institutions are the engine of good financial system and play a pivotal role in the economic growth, which help the investor to invest and get return. Therefore, development of a vibrant and active financial institution that complements existing public sector work is considered important to Ethiopia's economic progress. Banks, insurance companies and microfinance institutions were the major financial institutions operating in Ethiopia. As per 2018/19 report of National Bank of Ethiopia, the financial sector in Ethiopia currently consists of 18 banks, 16 were private and 2 state-owned. Banking is the dominant subsector, accounting for 78 percent of total financial sector assets (World Bank, 2019). Banking system plays a very important role in the economic life of the nation. The health of the economy is closely related to the soundness of its banking system. Modern trade and commerce would almost be impossible without the availability of suitable banking services. As result monitoring, supervision and continuous performance evaluation of the banking sector is compulsory to ensure the financial stability of the economy.

In Ethiopia, according to the National Bank, total capital of the banking industry increased by 18.4 percent and reached Birr 101.5 billion by the end of June 2019. In the country, one bank branch serves about 17 thousand people. About 34.6 percent of bank branches were located in the capital, Addis Ababa. Total resources mobilized by the banking system in the form of deposit, borrowing and loan collection increased by 3.4 percent and reached Birr 308.3 billion at the end of 2018/19 (NBE, 2019). According to Cepheus Research \& Analytics 2019, the Ethiopian banking sector has enjoyed high growth, high profits, and high returns almost without interruption for over a decade. Growth over the past ten years has been a very high annual rate of 28 percent for deposits, 31 percent for loans, and 22 percent for profits. In terms of absolute profit levels across African banking markets, a cross-country comparison shows Ethiopia's profit pool of \$816mn last year ranks fifth in the continent (Cepheus Research \& Analytics, 2019).

The objective of this paper is to analyze performance of private commercial banks using CAMEL analysis in Ethiopia. It is understandable that a more comprehensive analysis covering multiple aspects of performance is necessary to assess the overall financial health of banks. CAMEL approach is an effective tool to determine the relative financial strength of a bank and to suggest relevant measures to improve shortcomings of a bank (Barker and Holdsworth, 1993). Under this system, each banking institution subject to onsite examination is evaluated on the basis of five critical dimensions relating to its operations and performance, which are referred to as the component factors. These are Capital, Asset Quality, Management, Earnings and Liquidity used to reflect the financial performance, financial condition, operating soundness and regulatory compliance of the banking institution (Sahajwala \& Van denBergh, 2000). Even if the private banks are not as strong as the public banks their contribution and performance in the sector is increasing. According to 2019 NBE reports, the share of private banks in deposit mobilization increased to 29.1 percent and in loan collection $61.5 \%$ was collected by private banks.

Given the important role played by banks in the market economy as financial intermediaries and the competitive market in which banks are operating, it is important to study and evaluate their performance. The 
performance of banks is an issue of major interest for depositors, regulators, customers, investors and policy makers. Therefore, periodic performance evaluation of banks is beneficial for these stakeholders in order to understand the weakness, strength and damages banks causes to economy if not managed well. A periodic performance evaluation is needed because studies found that even if CAMELS ratings contain useful information, they depreciate quickly and viability of information of CAMELS ratings is short lived (Cole and Gunther $(1996,1998)$. Thus this paper try to see the performance of private commercial banks in Ethiopia.

\subsection{Objective of the Study}

The main objective of the study is to analyze Performance of Private Commercial Banks using the CAMEL rating method in Ethiopian Financial Sector.

\subsection{Banking Activity in Ethiopia}

Ethiopia is a country witnessing economic growth coupled with its growing financial institutions capacity. The history of modern financial institution in Ethiopia goes to 1905 when Bank of Abyssinia was established. This bank was owned by British and it was replaced by the Bank of Ethiopia in 1931 by the Ethiopian Government, becoming the first $100 \%$ African-owned bank on the continent. During Italian invasion the bank was closed and replaced by several Italian banks that opened their branches in the country. In 1943 the State Bank of Ethiopia was founded.

The State Bank of Ethiopia operated as both a commercial and central bank until 1963 when it was dissolved to form the central bank, the National Bank of Ethiopia (NBE), and the Commercial Bank of Ethiopia (CBE) (Alemayehu Geda 2001).

The banking sector was opened for private and foreign banks until the Derg regime control power in 1974. All of the sudden because of Derg's command economic policy the private financial institutions were nationalized. Ethiopia's financial sector remains closed and is much less developed than its neighbors. During this time financial institutions were basically executing the economic plans outlined by the central planning organ. In 1991 the military government Derg was overthrown by TPLF and other armed groups a new government was established with new policy. The economic policy change has resulted in significant change in the functioning of the financial sector. New private financial institutions were emerged as Awash Bank is the first private bank in the country followed by Dashen Bank and Bank of Abyssinia.

Ethiopian banking sector is characterized by being small, underdeveloped, closed, tight regulations and highly dominated by state owned commercial banks. The state- owned commercial banks account for nearly two-thirds of the banking sector assets. The level of financial intermediation in Ethiopia is low, in part due to the public's lack of confidence in the banking sector (Admasu and Asaye, 2014). Ethiopian banks are known for providing traditional banking services like simple deposit accounts, loans, guarantees, and Letters of Credit. According to Cepheus Research and Analystics 2019 in relation to other African and Asian countries, Ethiopia's private banks are: much smaller in size; very limited in their services; heavily focused on lending instead of other income sources; less burdened by bad loans; carrying lower overhead costs; and slightly more profitable than their peers.

\section{Literature Review}

Banking sector is an important and unquestionable determinant of the economic development as it directs the flow of the funds from surplus economic units of the economy towards deficit economic units. Banking industry being an important pillar of financial sector of an economy, its performance measurement cannot be neglected. This study tries to assess the performance of selected private commercial banks in Ethiopia. Ethiopian banking is flourishing.

According to Cepheus Research and Analytics 2019 report, the Ethiopian banking sector has enjoyed high growth, high profits, and high returns - almost without interruption - for over a decade. Growth over the past ten years has been a very high annual rate of 28 percent for deposits, 31 percent for loans, and 22 percent for profits.

A variety of methodologies are used to analyze bank performance. They include the CAMEL rating, Economic Value Added (EVA), Analytic Hierarchy Process (AHP), and data envelopment analysis (DEA). In this study CAMEL approach is used.

The CAMEL rating is a scheme for grading the performance of banks. It is an acronym which derived from the five major dimensions of a bank's operation: Capital adequacy, Asset quality, Management quality, Earnings ability and Liquidity (CAMEL). The purpose of CAMEL analysis is to provide an accurate and consistent evaluation of a bank's financial condition and operations in the aforementioned areas. Many studies have used CAMELS rating system to analyze the performance of financial institutions and found the system quite useful in terms of judging their financial conditions. Barker and Holdsworth (1993) found the evidence that CAMELS ratings are useful with regard to estimating bank failure, even after controlling for a wide range of publicly available information about the condition and performance of banks. Barr et al. (2002) described the CAMELS 
rating system used by bank examiners and regulators. Siva and Natarajan (2011) found that CAMEL scanning helps banks to diagnose its financial health and alert the bank to take preventive steps for its sustainability. Even if CAMEL rating used to indicate the strength and failure of a given bank, some studies indicate that they are periodical.

The viability of information of CAMELS ratings is short lived. Cole and Gunther (1998) in their studies found that even if CAMELS ratings contain useful information, they depreciate quickly. This why performance of banks should be evaluated periodically using the CAMEL approach.

\subsection{Components of the CAMEL Approach}

As discussed above CAMEL specifies the evaluation of financial institutions on the basis of five critical dimensions which are: Capital adequacy, Asset quality, Management, Earnings and Liquidity. These components are used to reflect financial performance, operating soundness and regulatory compliance of financial institutions. Muhammad (2009) claims that the strength of these factors would determine the overall strength of the bank. The quality of each component further underlines the inner strength and how far it can take care of itself against the market risks.

\subsubsection{Capital Adequacy}

The dimension of capital adequacy is an important factor to help the bank in understanding the shock attractive capability during risk. Capital adequacy is the capital expected to maintain balance with the risks exposure of the financial institution.

It indicates whether the bank has enough capital to absorb unexpected losses. That means, capital adequacy enables a bank to meet any financial unexpected condition due to credit risk, market risk and interest rate risk. According to (Reddy, 2012) Capital adequacy is required to maintain depositors' confidence and preventing the bank from going bankrupt. Chen (2003) also recommended that to prevent the bank from failure, it is necessary to maintain a significant level of capital adequacy. Capital Adequacy is a prominent indicator of the financial soundness. Satisfactory CAR prevents the bank from bankruptcy. Capital Adequacy shields depositors against the risks and promotes the stability of financial systems (Masoud G. and Bayraktar, 2018).

\subsubsection{Asset Quality}

Banks' management is required to constantly evaluate the health and quality of their assets specifically loan by keeping track of the financial health of their borrowers. Frost (2004) stresses that the asset quality indicators highlight the use of non-performing loans ratios (NPLs). According to Grier (2007), "poor asset quality is the major cause of most bank failures". Asset quality referred to as well as credit risk since the banks' primary activity is lending money. The greatest risk facing the bank is the risk of loan losses derived from the negligent loans.

\subsubsection{Management Quality}

Management Efficiency is basically the capability of the board of directors and management, to identify, measure, and control the risks of an institution's activities and to ensure the safe, sound, and efficient operation in compliance with applicable laws and regulations (Uniform Financial Institutions Rating System 1997, p. 6 as cited in Uyan Dang 2011). It is the subjective part of the CAMEL framework since it reflects all the qualitative aspects of a bank such as, the organizational culture, management system, compliance with the internal and external norms and policies. It indicates the growth and survival of the bank. Management efficiency means adherence to standard of norms, ability to plan and respond to changing environment leadership and administrative capability of the bank.

\subsubsection{Liquidity}

Banks are in a business where liquidity is of prime importance. Liquidity is the banks capacity to meet its short term obligations as well as loan commitments. Liquidity is most important parameter especially in banking sector as banks are considered as liquidity creator in the market.

There should be adequacy of liquidity sources compared to present and future needs, and availability of assets readily convertible to cask without undue loss. Rudolf (2009) emphasizes that "the liquidity expresses the degree to which a bank is capable of fulfilling its respective obligations". Banks makes money by mobilizing short-term deposits at lower interest rate, and lending or investing these funds in long-term at higher rates, so it is hazardous for banks mismatching their lending interest rate.

\subsubsection{Earning Ability}

Earning is an important parameter to measure the financial performance of an organization. Earning quality mainly measures the profitability and productivity of the bank, explains the growth and sustainability of future earnings capacity. This rating reflects not only the quantity and trend in earning, but also the factors that may affect the sustainability of earnings. Inadequate management may result in loan losses and in return require higher loan allowance or pose high level of market risks. The future performance in earning should be given equal or greater value than past and present performance. (Uniform Financial Institutions Rating System 1997, p.7 as cited in Uyen Dang 2011). Grier (2007) said a consistent profit not only builds the public confidence in 
the bank but absorbs loan losses and provides sufficient provisions. It is also necessary for a balanced financial structure and helps provide shareholder reward. Thus consistently healthy earnings are essential to the sustainability of banking institutions. Profitability ratios measure the ability of a company to generate profits from revenue and assets. Earning ability identifies the sustainability and future growth of the bank.

\section{Research Method}

The present study has been conducted to evaluate the financial performance of 3 privately-owned commercial banks currently operating in Ethiopia. According to 2019 report of National Bank of Ethiopia there are 16 private banks in Ethiopia. For this study 3 private banks are purposively selected. This study is predominantly based on secondary data which has been collected from the financial statements and annual reports of respective banks for the period of 2013 to 2019.

This time period was selected because it is a time were Ethiopia experienced political instability and social unrest. Dominantly the unrest was happened in Oromia region. Therefore, three private banks which dominantly operate in the region are taken as a sample. The banks are Awash Bank (AB), Cooperative Bank of Oromia $(\mathrm{CBO})$ and Oromia International Bank (OIB).

The CAMEL rating framework has been used in this study to rank the selected banks based on their performances. For the purpose of this study, 10 sub-parameters under CAMEL model have been considered which are associated with different dimensions of financial performance analysis. The variables considered in this study are capital adequacy measured by equity to asset ratio (Zülfiyye, 2006), asset quality measured by loan loss reserve to gross loans (Koch, 1995), management efficiency measured by profit per employee ratio and total cost to total income ratio (Sangmi \& Nazir, 2010), earning ability measured by return on assets (ROA) (Ayadi \& Pujals, 2005); Athanasoglou, Brissimis \& Delis, 2005) and liquidity measured by liquid assets to total asset and liquid assets to total deposits (Routledge \& Gadenne, 2000); Arena, 2005).

\section{Discussion and Analysis}

In this section of the study the CAMEL elements of the bank under the study were analyzed. Each element, Capital Adequacy, Asset quality, Management Efficiency, Earning and Liquidity ratios has been analyzed by using the Awash Bank, Cooperative Bank of Oromia and Oromia International Bank annual reports. The study covered a seven year data from the year 2013 to 2019 G.C.

\subsection{Presentation of Sample Banks}

Here the number of employees and number of branches the sample banks: Awash Bank (AB), Cooperative Bank of Oromia (CBO) and Oromia International Bank (OIB) are discussed.

Table 1: Number of Branches and Employees

\begin{tabular}{|c|c|c|c|c|c|c|c|c|}
\hline Items & Bank & 2013 & 2014 & 2015 & 2016 & 2017 & 2018 & 2019 \\
\hline \multirow{3}{*}{$\begin{array}{ll}\text { No of } \\
\text { Branches }\end{array}$} & $\mathrm{AB}$ & 115 & 150 & 202 & 240 & 316 & 366 & 410 \\
\hline & $\mathrm{CBO}$ & 78 & 106 & 141 & 174 & 256 & 298 & 389 \\
\hline & OIB & 65 & 106 & 151 & 200 & 223 & 248 & 265 \\
\hline \multirow{4}{*}{$\begin{array}{l}\text { No of } \\
\text { Employees }\end{array}$} & Bank & 2013 & 2014 & 2015 & 2016 & 2017 & 2018 & 2019 \\
\hline & $\mathrm{AB}$ & 4011 & 4787 & 5847 & 6003 & 6772 & 7881 & 9046 \\
\hline & $\mathrm{CBO}$ & 1427 & 1636 & 1957 & 2286 & 2,956 & 3,505 & 4,369 \\
\hline & OIB & 1336 & 1883 & 2425 & 2880 & 3066 & 3266 & 3647 \\
\hline
\end{tabular}

Source: Financial Reports of the banks

Table above indicates that in terms of number of branches and number of employees Awash is the leading bank followed by Cooperative Bank of Oromia and International Bank of Ethiopia. The table shows that the banks number of branches are growing from time to time.

For the last six years the number of branches was growing by $23.9 \%, 30.1 \%$ and $27.9 \%$ for Awash Bank, Cooperative Bank of Oromia and Oromia International Bank respectively. The Banks are relying on large-scale branch expansions, broadened their geographic reach over the past six years, thus improving access to finance. In the last six years in terms of number of employees Awash Bank was growing by $14.6 \%$ on average, Cooperative Bank of Oromia was growing by $20.6 \%$ on average and Oromia International Bank was growing by $18.8 \%$ on overage. This shows Cooperative Bank of Oromia's growth rate is higher compared to the two banks. 


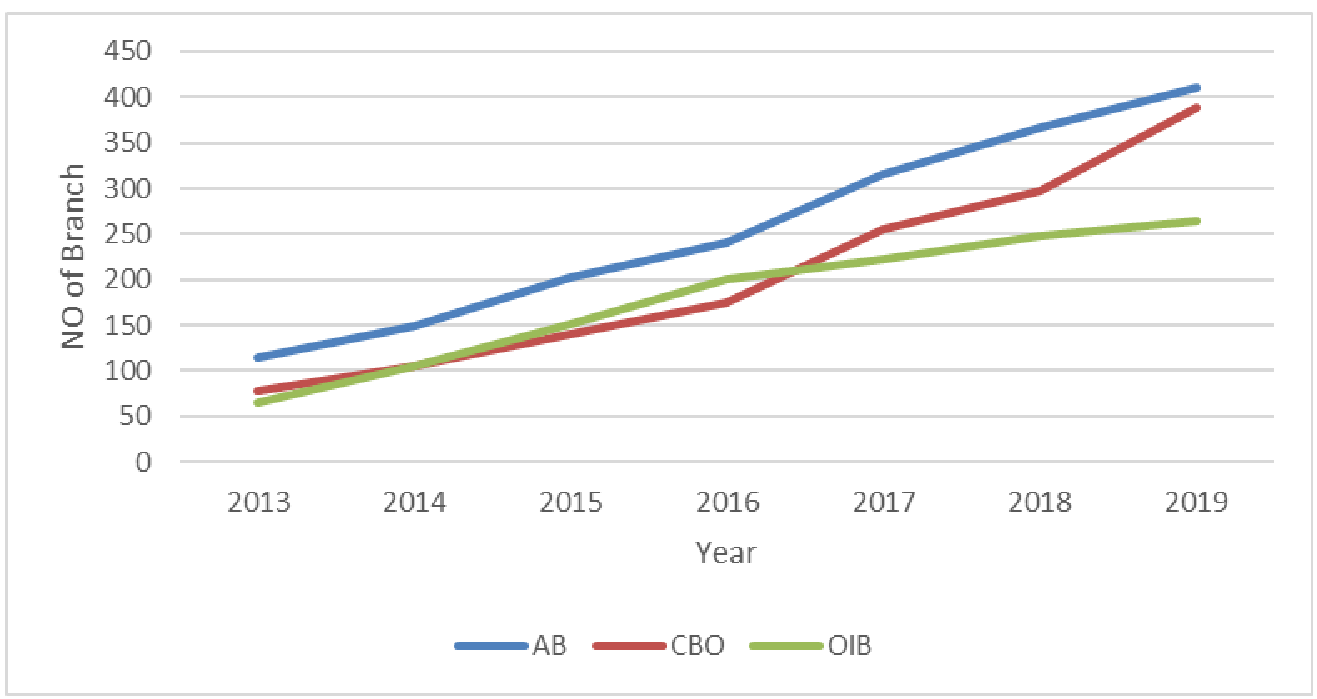

Figure 1: Number of Branches

Figure indicates that the banks are increasing their expansion in branch opening over the last seven years. The chart shows that there is a decrease in growth of branches in 2014, 2016 and 2018 for the banks. In this year's Ethiopia experienced political unrest particularly in oromia region where this banks dominantly operate. This could be one of the cause for the decline in growth in branch expansion of the banks.

\subsection{Capital Adequacy}

Capital adequacy is the capital excepted to be maintained by the banks to protect depositors and shareholders if losses happened. It shows the strength and stability of banks.

The ratios used to assess the capital adequacy of the banks and their desirable nature are given in the table 3 and discussed in the following section.

Table 2: Capital Adequacy Ratio

\begin{tabular}{|c|c|c|c|c|c|c|c|c|}
\hline Ratio & Bank & 2013 & 2014 & 2015 & 2016 & 2017 & 2018 & 2019 \\
\hline \multirow{3}{*}{$\begin{array}{l}\text { Total Capital to } \\
\text { Total Asset }\end{array}$} & $\mathrm{AB}$ & $11.6 \%$ & $11.7 \%$ & $12.6 \%$ & $12.6 \%$ & $11.4 \%$ & $11.7 \%$ & $12.9 \%$ \\
\hline & $\mathrm{CBO}$ & $10.6 \%$ & $14.8 \%$ & $12.3 \%$ & $11.4 \%$ & $8.1 \%$ & $7.9 \%$ & $7.8 \%$ \\
\hline & OIB & $14 \%$ & $12.2 \%$ & $10.4 \%$ & $11.6 \%$ & $11.3 \%$ & $10.9 \%$ & $11.7 \%$ \\
\hline
\end{tabular}

Source: Compilation from financial reports of the banks

Table 2 clearly reveals information about the capital adequacy of different banks based on capital to total asset ratio. From the above table the capital to asset ratio of Cooperative bank of oromia is smaller than Awash Bank and Oromia international Bank. The higher ratio indicates that the bank is adequately capitalized to its operation expansion, investors are protected, and the bank is stronger. Therefore, Awash Bank stood first which shows the bank stronger than the two banks.

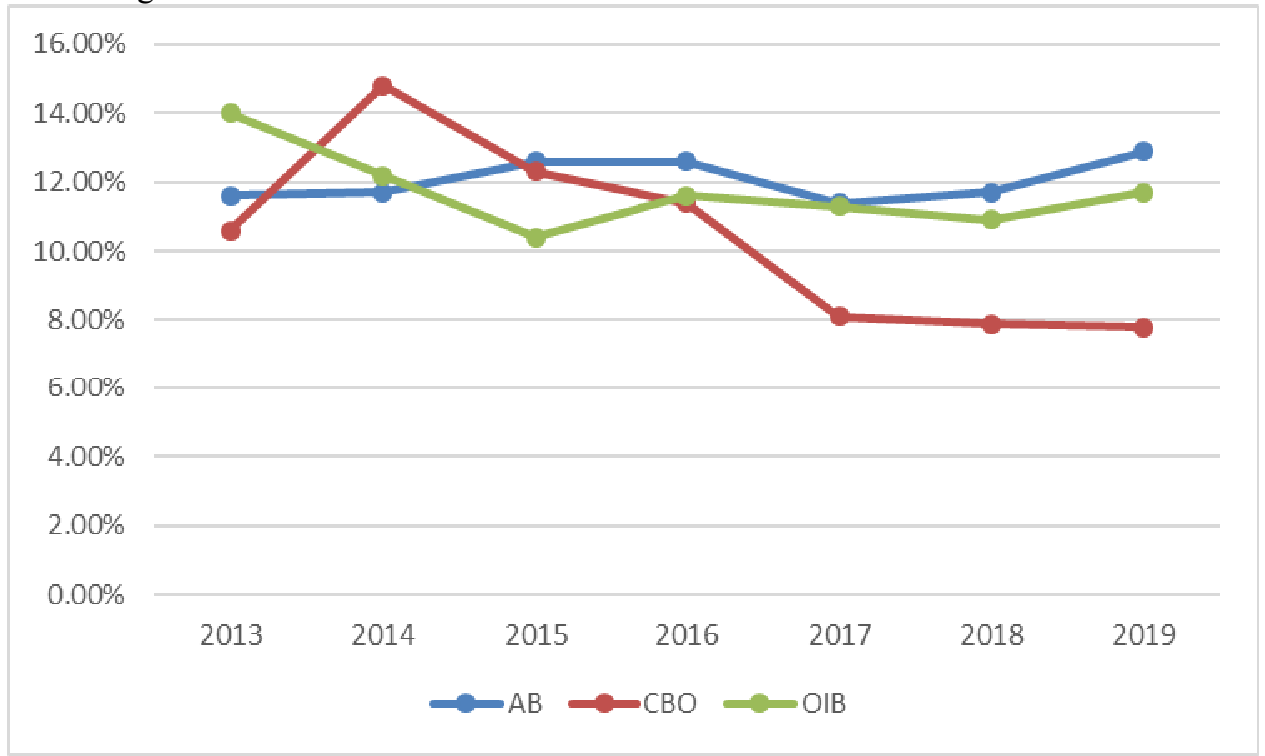

Figure 2: Capital Adequacy Ratio of Banks 
The above figure indicates the total capital to total asset ratio of Cooperative bank of Oromia is decreased in 2015, 2016, 2017 and 2018. The total capital to total asset ratio of Awash Bank and Oromia International Bank decreased in 2017 and 2015 respectively. This may indicate that the political and social unrest that occurred in the region in the time period highly affected Cooperative Bank of Oromia.

\subsection{Asset Quality}

Asset Quality is used to assess the credit risk of banks and how effectively the banks are working in monitoring the credit risk. In this paper, it is measured by the provision for loan loss to total loan and loan to total asset ratio. Table 3: Asset Quality Ratios

\begin{tabular}{|c|c|c|c|c|c|c|c|c|c|c|}
\hline \multirow{8}{*}{$\begin{array}{l}\text { Asset } \\
\text { Quality }\end{array}$} & Ratio & Bank & 2013 & 2014 & 2015 & 2016 & 2017 & 2018 & 2019 & Average \\
\hline & \multirow{3}{*}{$\begin{array}{l}\text { Loan to } \\
\text { Total Asset }\end{array}$} & $\mathrm{AB}$ & 0.423 & 0.405 & 0.487 & 0.488 & 0.529 & 0.561 & 0.627 & 0.5 \\
\hline & & $\mathrm{CBO}$ & 0.557 & 0.283 & 0.573 & 0.547 & 0.535 & 0.492 & 0.512 & 0.5 \\
\hline & & OIB & 0.408 & 0.412 & 0.494 & 0.457 & 0.483 & 0.418 & 0.482 & 0.45 \\
\hline & & Bank & 2013 & 2014 & 2015 & 2016 & 2017 & 2018 & 2019 & \\
\hline & \multirow{3}{*}{$\begin{array}{l}\text { Loan loss } \\
\text { Provision to } \\
\text { Gross Loan }\end{array}$} & $\mathrm{AB}$ & 0.023 & 0.023 & 0.017 & 0.015 & 0.015 & 0.008 & 0.008 & 0.015 \\
\hline & & $\mathrm{CBO}$ & 0.009 & 0.018 & 0.026 & 0.099 & 0.045 & 0.024 & 0.033 & 0.036 \\
\hline & & OIB & 0.015 & 0.013 & 0.013 & 0.018 & 0.025 & 0.009 & 0.009 & 0.014 \\
\hline
\end{tabular}

Source: Compilation from financial reports of the banks

Table 3 indicates that Cooperative Bank of Oromia and Awash Bank loan to total asset ratio is almost equal on average for the last seven years. Oromia International Bank has lower ratio. The higher ratio indicates the aggressiveness of bank in lending. In 2014 the ratio of total loan to total asset ratio of Cooperative Bank of Oromia is smaller which shows the bank's lending activity was reduced. In the year loan decreased by $42.9 \%$ and in 2016 total asset decreased by $10.8 \%$.In terms of loan loss provision to total loan ratio Oromia international bank has the lowest ratio which shows low credit risk. Since a high ratio means a bad quality of assets, CBO's asset quality compared to others is low.

\subsection{Management Quality}

Management quality is the ability of the management to detect and manage risk, and make sure safety and sound operation of the banks. Management efficiency can be measured according to Sangmi and Nazir (2010) by the expenditure to income ratio and earning per employee ratio.

Table 4: Management Quality

\begin{tabular}{|c|c|c|c|c|c|c|c|c|c|c|}
\hline \multirow{8}{*}{$\begin{array}{l}\text { Management } \\
\text { Quality }\end{array}$} & Ratio & Bank & 2013 & 2014 & 2015 & 2016 & 2017 & 2018 & 2019 & AVG \\
\hline & \multirow{3}{*}{$\begin{array}{l}\text { Total } \\
\text { Expense } \\
\text { to Total } \\
\text { Income }\end{array}$} & $\mathrm{AB}$ & 0.589 & 0.568 & 0.625 & 0.65 & 0.641 & 0.636 & 0.585 & 0.61 \\
\hline & & CBO & 0.649 & 0.609 & 0.745 & 0.965 & 0.842 & 0.721 & 0.794 & 0.76 \\
\hline & & OIB & 0.693 & 0.624 & 0.653 & 0.721 & 0.742 & 0.619 & 0.690 & 0.67 \\
\hline & \multirow{4}{*}{$\begin{array}{l}\text { Profit per } \\
\text { employee } \\
\text { in Birr }\end{array}$} & Bank & 2013 & 2014 & 2015 & 2016 & 2017 & 2018 & 2019 & \\
\hline & & $\mathrm{AB}$ & 109351 & 129155 & 93267 & 123899 & 148100 & 189370 & 268939 & 151725 \\
\hline & & $\mathrm{CBO}$ & 132628 & 210145 & 159651 & 17111 & 114406 & 149334 & 150552 & 133403 \\
\hline & & OIB & 58435 & 81966 & 91462 & 86221 & 97062 & 222812 & 204511 & 120352 \\
\hline
\end{tabular}

Source: Compilation from financial reports of the banks

Table 4 indicates cost to income ratios of Cooperative Bank of Oromia is higher compared to Awash Bank and Oromia International Bank.

The ratio is higher particularly in 2015, 2016 and 2017 for Cooperative Bank of Oromia and Oromia International Bank. According Cepheus Analytics 2019, cost to income ratios of private banks in Africa and Emerging markets economies are $60 \%$ to $65 \%$. Cost-to-income ratio of Cooperative Banks of Oromia is considerably higher compared to African and Emerging economies private banks. The rise in the cost to income ratios particularly in, 2015, 2016 and 2017 could be attributed to the political and social unrest in region where the bank dominantly operate. During this period according to Margaux and Clionadh (2017), there was an average of 26 per week demonstrations and riot in the region. In profit per employee perspective Awash Bank is the better bank followed by CBO. 


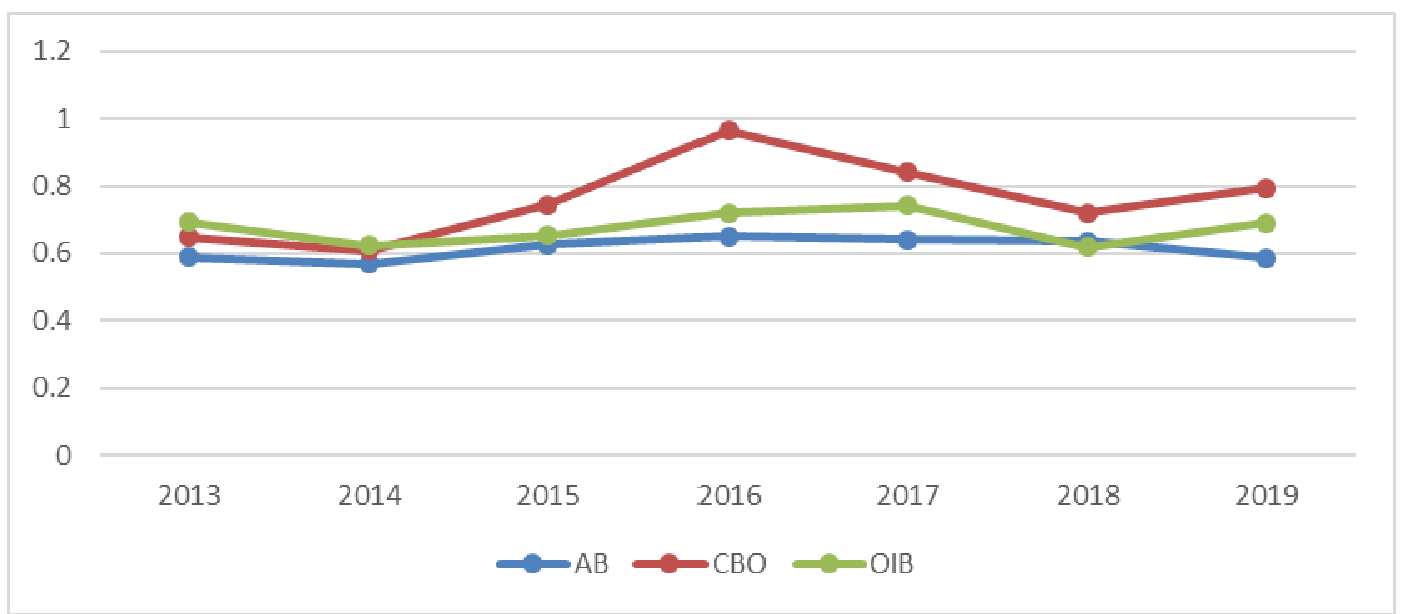

Figure 3: Cost to income ratio of banks

Figure 3 shows that the cost to income ratio of Cooperative Bank of Oromia is increased so high in 2016. This because of the decreases income and rise in expenses of the banks. Based on the financial data from the financial reports of bank income of the bank decreased by $12 \%$ in 2016 . This decrease in income could be attributed the social unrest and the political turmoil in the region which highly affected the service and performance of the bank.

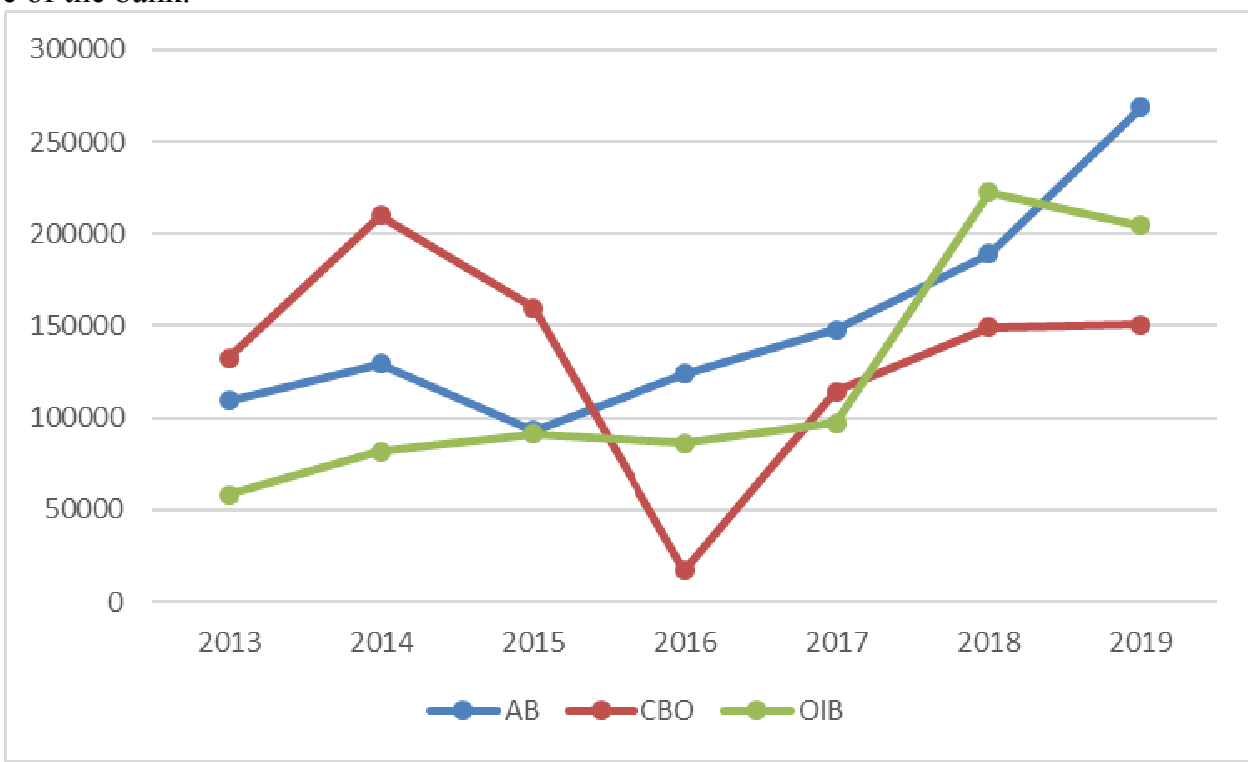

Figure 5: Profit per employee of the banks in thousand birr

Profit per employee indicates the productivity and efficiency of human resources of bank and indicates the average profit generated per person employed by a bank. Figure 5 indicates that profit per employee of Cooperative Bank of Oromia has decreased in a significant amount in 2016 with a percentage of $89 \%$. The profit per employee of Awash Bank decreased with $27 \%$ in 2015 and that of Oromia International Bank decreased by $5.7 \%$ and $8.2 \%$ in 2016 and 2019 respectively. This shows how much the political environment of 2015, 2016 and 2017 affected the efficiency of banks and their employees.

\subsection{Earning Ability}

Earning Ability shows the profitability and the ability of banks to generate more profits from its asset. It indicates the sustainability and future growth of banks.

Table 5: Earning Ability Ratios

\begin{tabular}{|c|c|c|c|c|c|c|c|c|c|c|}
\hline \multirow{4}{*}{$\begin{array}{l}\text { Earning } \\
\text { Ability }\end{array}$} & Ratio & Bank & 2013 & 2014 & 2015 & 2016 & 2017 & 2018 & 2019 & Average \\
\hline & \multirow{3}{*}{ ROA } & $\mathrm{AB}$ & $2.50 \%$ & $2.80 \%$ & $2.10 \%$ & $2.40 \%$ & $2.40 \%$ & $2.70 \%$ & $3.20 \%$ & $2.58 \%$ \\
\hline & & $\mathrm{CBO}$ & $2.80 \%$ & $4.60 \%$ & $2.70 \%$ & $0.40 \%$ & $1.90 \%$ & $1.70 \%$ & $1.50 \%$ & $2.23 \%$ \\
\hline & & OIB & $1.90 \%$ & $2.50 \%$ & $2.30 \%$ & $2.20 \%$ & $2.10 \%$ & $3.10 \%$ & $2.30 \%$ & $2.34 \%$ \\
\hline
\end{tabular}

Source: Compilation from financial reports of the banks

Table 5 shows the return on asset of banks used to measure the earning ability and profitability of the banks. Based on the above table on average for the last seven years Awash Bank was generating 2.58\% from each birr 
of its asset.

From the three banks Awash Bank is the leading bank in profitability as measured by ROA. Compared to industry average profits after tax of $2.8 \%$, the banks profit after tax is lower.

Figure 7: Return on Asset of Banks

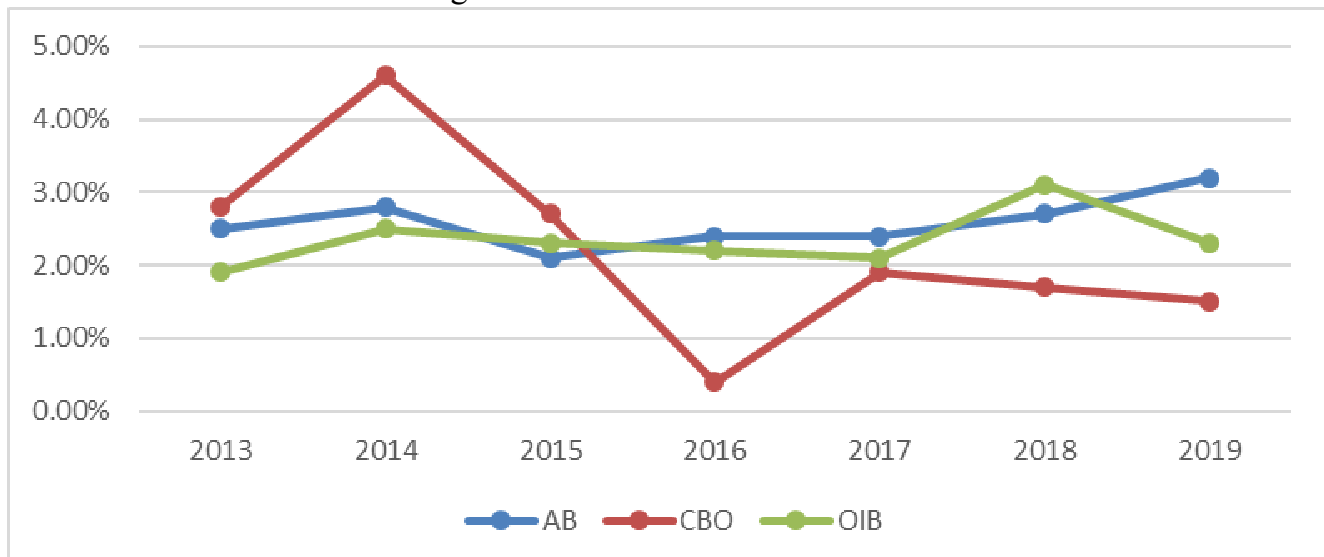

Source: Compilation from financial reports of the banks

Figure 7 indicates that the profit after tax ratio to total asset of Cooperative Bank of Oromia was decreased in 2015 and 2016. Based on the financial reports the net income after profit of the bank decreased by $9 \%$ in 2015 and by $87 \%$ in 2016 . The bank registered a net profit of 39 million birr only in 2016 compared to $312,438,109$ million birr in 2015. In 2016 CBO's profitability was highly affected by the political and social unrest of the time.

\subsection{Liquidity}

Table 6: Liquidity Ratios

\begin{tabular}{|c|c|c|c|c|c|c|c|c|c|c|}
\hline \multirow{8}{*}{ Liquidity } & Ratio & Bank & 2013 & 2014 & 2015 & 2016 & 2017 & 2018 & 2019 & $\mathrm{Av}$ \\
\hline & \multirow{4}{*}{$\begin{array}{l}\text { Liquid } \\
\text { Asset to } \\
\text { Total } \\
\text { Asset }\end{array}$} & $\mathrm{AB}$ & $19.20 \%$ & $22.80 \%$ & $15.40 \%$ & $5.60 \%$ & $16.70 \%$ & $21.10 \%$ & $15.20 \%$ & 16.5 \\
\hline & & $\mathrm{CBO}$ & $45.90 \%$ & $23.90 \%$ & $20.30 \%$ & $19.90 \%$ & $19.90 \%$ & $25.60 \%$ & $17.10 \%$ & 24.6 \\
\hline & & OIB & $25.40 \%$ & $30.30 \%$ & $17.50 \%$ & $19.00 \%$ & $22.80 \%$ & $24.40 \%$ & $16.10 \%$ & 22.2 \\
\hline & & Bank & 2013 & 2014 & 2015 & 2016 & 2017 & 2018 & 2019 & \\
\hline & \multirow{3}{*}{$\begin{array}{l}\text { Liquid } \\
\text { Asset to } \\
\text { Deposit }\end{array}$} & $\mathrm{AB}$ & $27.20 \%$ & $33.60 \%$ & $20.90 \%$ & $7.70 \%$ & $22.90 \%$ & $26.70 \%$ & $19.10 \%$ & 22.5 \\
\hline & & $\mathrm{CBO}$ & $67.20 \%$ & $32.20 \%$ & $31.50 \%$ & $25.10 \%$ & $25.20 \%$ & $30.20 \%$ & $20.00 \%$ & 33 \\
\hline & & OIB & $32.50 \%$ & $37.30 \%$ & $20.90 \%$ & $22.90 \%$ & $29.10 \%$ & $34.30 \%$ & $22.80 \%$ & 28.5 \\
\hline
\end{tabular}

Source: Compilation from financial reports of the banks

Table 6 shows that the liquid asset to total asset ratio of Awash Banks is $16.5 \%$ on average for last seven years, 24.6\% for Cooperative Bank of Oromia and 22.2\% for Oromia International Bank. Cooperative Bank of Oromia rank first in both in liquid asset to total asset ratio and liquid asset to deposit ratio.

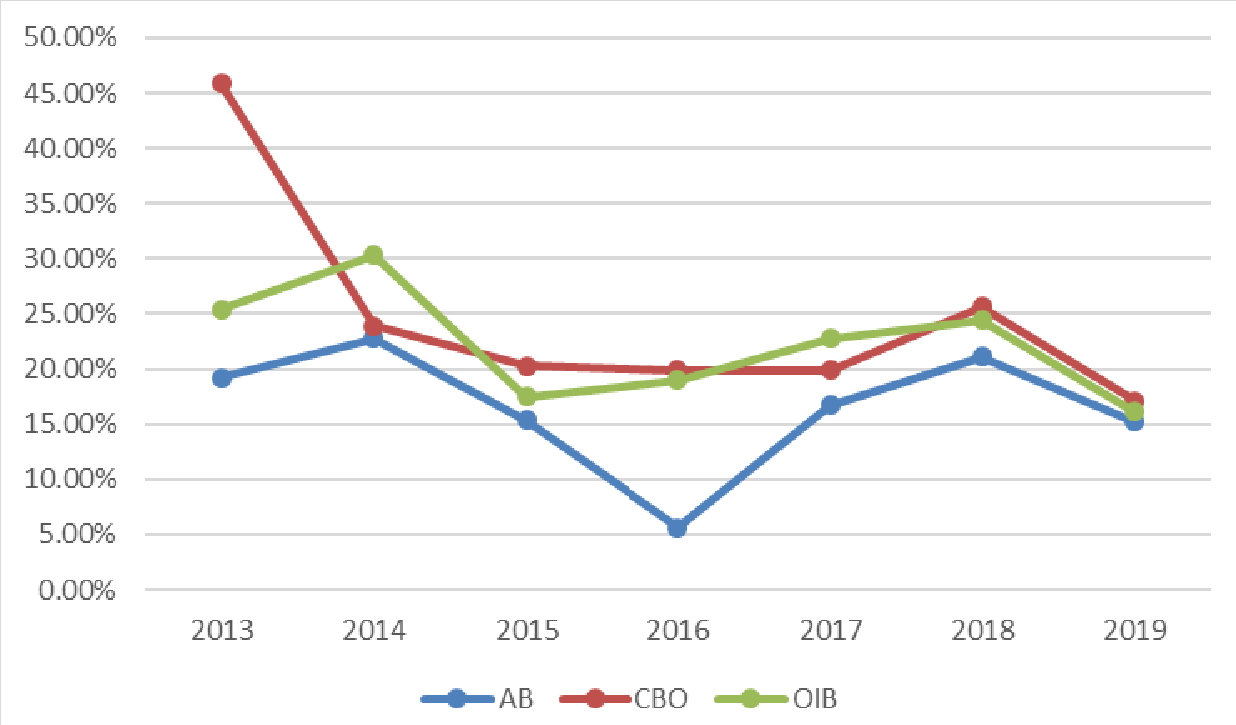

Figure 8: Liquid asset to total asset ratio 
Figure 8 shows that the liquidity position of Awash Bank in terms liquid asset to total asset ratio has decreased in 2014, 2015, 2016 and 2019. In 2019 all the three banks liquidity ratio was decreased. In 2019 there was COVID 19 lock down for months in the country which may affected the liquidity position of the banks.

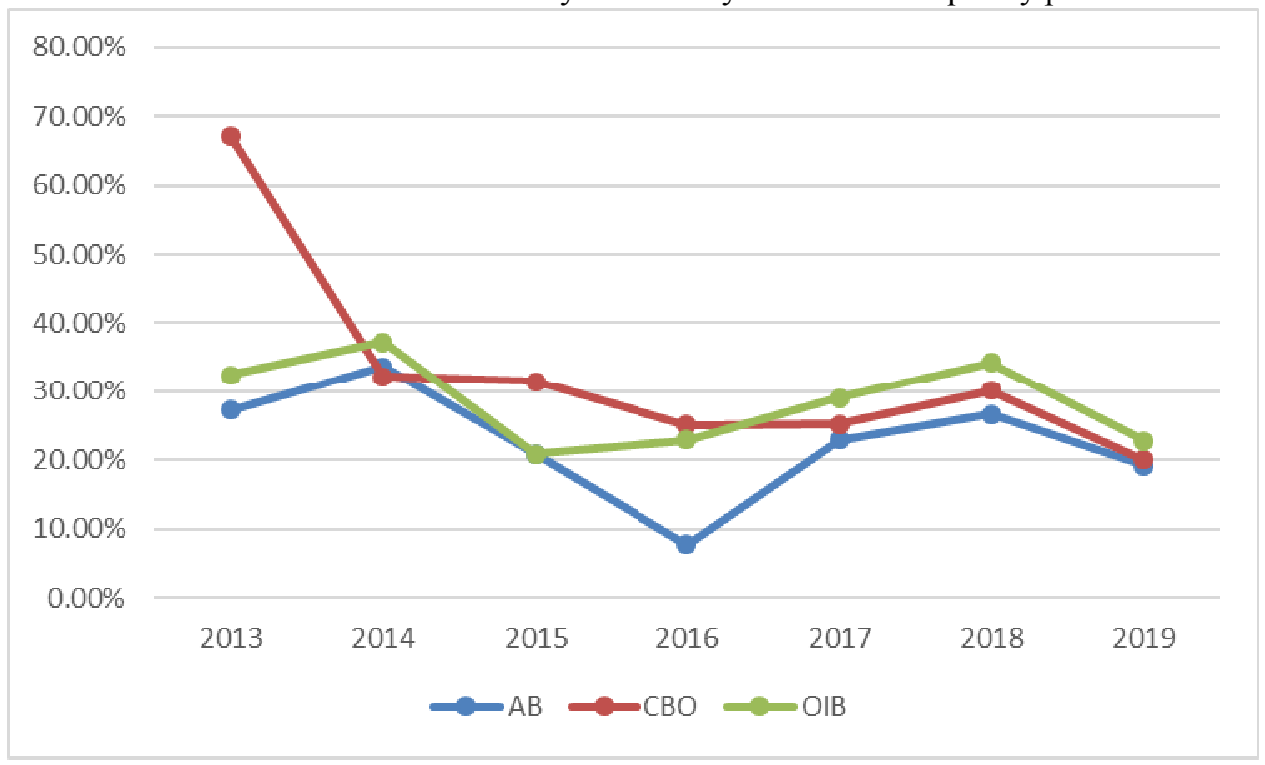

Figure 9: Liquid asset to deposit ratio

Figure 9 shows that the liquidity position of all the three banks in terms of liquid asset to deposit ratio has decreased in 2019. The decrease could be because of COVID 19.

\section{Conclusion}

The study measures the performance of three private commercial banks in Ethiopia. The CAMEL analysis was chosen to evaluate the performance of Awash Bank, Cooperative Bank of Oromia and International Bank of Oromia based on five elements which are Capital Adequacy, Asset Quality, Management Efficiency, Earning Quality, and Liquidity. Annual data is utilized to compute performance of banks from the period of 2013 to 2019. This three private banks largely operate in Oromia which is largest regional state in Ethiopia. Beginning from 2014 to 2018 until a new prime minister was elected there were massive protest and social unrest in the country particularly in Oromia region. The performance of the banks in this environment as measured by CAMEL shows that efficiency in terms of cost to income ratio increased for Cooperative Bank of Oromia. The bank was highly affected as total income decreased by $12 \%$, net income decreased by $87 \%$, profit per employee decreased by $89 \%$, total asset decreased by $6.7 \%$ and loan decreased by $10.8 \%$ in 2016 . The finding implies concentration of banks in specific region would have negative impact during crisis on bank performance and employees productivity also affected by the crisis. Therefore, management of the banks should diversify their operation across regions and should expand their customer base in different parts of the country. Further research should be done to see how much the political situation of the time affected bank performance in the country and the consequence of bank formation based ethnicity.

\section{Reference}

1. Addison T, Alemayehu G (2001). "Ethiopia's New Financial Sector and its Regulation", Discussion Paper No. 2001/55, World Institute for Development Economic Research (Wider).

1. Ademasu B.\&Asayeheng D.(2014). Banking Sector Reform in Ethiopia; International Journal of Business and Commerce; Vol. 3, No.8: Apr 2014[25-38]

2. Arena, M (2005). Bank failures and bank fundamentals: A comparative analysis of Latin East Asia during the nineties using bank-level data. Bank of Canada, Working paper. 47-62

America and

3. Athansasoglou, P., Brissimis, S., Delis, M. (2006). Bank-Specific, Industry-Specific and Macroeconomic Determinants of Bank Profitability. Journal of International Financial Markets, Institutions and Money. 121-136.

4. Ayadi, R., Pujals, G. (2005). Banking Mergers and Acquisitions in the EU: Overview, Assessment and Prospects. Paper presented at the European Money and Finance Forum. 35-47.

5. Baral, K.J. (2005). Health Check-up of Commercial Banks in the Framework of CAMEL: A Case Study of Joint Venture Banks in Nepal. Journal of Nepalese Business Studies, II (1), 41-55.

6. Barker D., \& Holdsworth D. (1993). The Causes of Bank Failures in the 1980s, Research Paper No. 9325. New York: Federal Reserve Bank of New York. 
7. Barr, R. S., Killgo, K. A., Siems, T. F., \&Zimmel, S. (2002). Evaluating the productive efficiency and performance of US commercial banks.Managerial Finance, 28(8), 3-25. https://doi.org/10.1108/03074350210767988

8. Barr, Richard S, Seiford, Lawrence M, and Siems, Thomas F,2002, ' Forecasting Bank

9. Cepheus Research \& Analytics.(2019) working paper on Ethiopian Banking Sector unpublished

10. Chen, J. (2003). "Capital adequacy of Chinese banks: Evaluation and enhancement", Journal of international banking regulation, 4(4), 320-327.

11. Cole R. A., \& Gunther .J.W. (1998). "Predicting bank failures: A comparison of on- and off-site monitoring systems. Journal of Financial Services Research. 13(2), 103-117.

12. Duttweiler, Rudolf (2009). "Managing Liquidity in Banks: A Top down Approach'. John Wiley and Sons, p1.Failure: A Non-Parametric Frontier Estimation Approach”, retrieved February 2, 2012

13. Frost, Stephen M. (2004). "Chapter 20 - Corporate Failures and Problem Loans", The Bank Analyst's Handbook: Money, Risk and Conjuring

14. Grier, Waymond, A. (2007). Credit Analysis of Financial Institutions. 2nd ed. Euromoney Institution Investor PLC. 8-10.

15. Koch, T.W. (1995). Bank Management. 3rd edition. The Dryden Press. London. Kongiri, A. (2012). Effects of Camel Variables on Bank Efficiency: a Panel Analysis of kenyan Commercial Banks. The Journal of Finance, 7-27.

16. Masoud G. and Bayraktar S. (2018). 'Performance Analysis of Banks in Turkey Using Camels Approach Case Study: Six Turkish Banks During 2005 To 2016. Journal of business research turk, DOI: 10.20491/isarder.2018.458

17. Muhammad, Haidar. (2009). "Banks and Camels", Available at: http://ezinearticles.Com/?Banks-AndCamelsandId $=2565867$, accessed on15th January, 2015.

18. National Bank of Ethiopia. (2019). Annual Report 2017/18. Addis Ababa

19. Pinaud, M. \& Raleigh,C. (2017,June 16) https://theglobalobservatory.org/2017/06/ethiopia-protests-oromoaddis-ababa-master-plan/june 162017

20. Reddy, K.S. 2012. Relative Performance of Commercial Banks in India Using Camel Approach. International Journal of Multidisciplinary Research, 2(3): 38-58.

21. Routledge, J., Gadenne, D. (2000). Financial distress, reorganization and corporate performance. Accounting and Finance. 233-240.

22. Sahajwala, R., \& Van den Bergh, P. (2000). Supervisory risk assessment and early warning systems. Basle Committee on Banking Supervision Working Papers, No. 4, Bank of International Settlements.

23. Sangmi, M., \& Nazir, T.(2010). Analyzing Financial Performance of Commercial Banks in India : Application of CAMEL Model. Pakistan Journal Commerce and Social Science, 4(1), 40-55.

24. Sangmi, M., \& Tabassum, N. (2010). Analyzing Financial Performance of Commercial Banks in India: Application of CAMEL model. Pakistan Journal of Commerce \& Social Sciences, 4(1), 40-55.

25. Uniform Financial Institutions Rating System (1997). Statements of Policy. The United States: Federal Deposit Insurance Corporation (FDIC).

26. Uyen, D. (2011). The CAMEL rating system in banking supervision. Journal of International Business Studies. 37-40.

27. World Bank (2019). Global Development Finance, Washington DC: The World Bank.

28. Zülfiyye, N. (2006). Factors Affecting the Profitability of Azerbaijan Banking System. Journal of Finance and Bank Management. 29-45. 